\title{
Schwerpunkt
}

\section{Childhood, Emotions and the Labour of Transnational Families}

\author{
Kanwal Mand
}

\begin{abstract}
This paper focuses on children of Bangladeshi heritage who are born in London and are mobile between the (trans) localities of East London and their ancestral home land of Sylhet (a district of Bangladesh). 'Being there' in Sylhet is intimately related to children's membership of transnational families and most of them recorded 'being there' on two occasions by the age of 11. The paper demonstrates that while there has been considerable attention on South Asian first and second generation transnationalism, comprising a focus on marital strategies, remittances, cultural productions and roots tourism, little is known about young children's transnational experiences or practices. The omission of children in part reflects a broader trend, wherein children until recently have been marginal in migration research, but more specifically stems from an emphasis on socialization. Hence South Asian children are constructed as passive members of transnational families. In this paper, I draw from a broader literature that highlights transnational ways of being to involve gendered labour which includes emotions and, I argue, this is necessary to locate children as active agents in the context of familial transnationalism.
\end{abstract}

Keywords: Childhood, Families, South Asian transnationalism, Labour, Emotions.

Kindheit und Emotionsarbeit in transnationalen Familien

\section{Zusammenfassung}

Der Beitrag befasst sich mit Kindern, die in London geboren sind, deren familiärer Herkunftsort Bangladesch ist und die zwischen den beiden (Trans)Lokalitäten East London und Sylhet (einem Distrikt in Bangladesch) mobil sind. Das „Dort-Sein“ in Sylhet ist eng verknüpft mit ihrer Zugehörigkeit zu einer transnationalen Familie. Meistens berichten diese Kinder, mit elf Jahren bereits zweimal dort gewesen zu sein. Während Transnationalisierungsprozesse in der ersten und zweiten Generation der Einwanderer/innen aus Südasien in der Forschung viel Aufmerksamkeit fanden - so etwa die Heiratsstrategien, der Rücktransfer von Gütern und Kulturproduktionen sowie der Heimattourismus - ist über die transnationalen Erfahrungen und Praktiken der Kinder nur wenig bekannt. Das Übersehen von Kindern spiegelt eine allgemeine Tendenz in der Migrationsforschung, die Kinder bis vor kurzem nur am Rande thematisiert hat. Diese Entwicklung ist nicht zuletzt dem hohen Stellenwert geschuldet, der Sozialisationsprozessen zugemessen worden ist und innerhalb derer Kinder als passive Mitglieder in transnationalen Familien konzeptionalisiert wurden. Der vorliegende Beitrag stellt die bestehende Literatur zu transnationalen $\mathrm{Zu}$ gehörigkeiten in einen Zusammenhang zu geschlechtsspezifisch markierter Emotionsarbeit. Nur über diesen Zusammenhang, so wird hier argumentiert, kann die Bedeutung von Kindern als eigenständigen Akteur/-innen in familiären Transnationalisierungsprozessen herausgearbeitet werden.

Schlagworte: Kindheit, Familien, Südasiatischer Transnationalismus, Arbeit, Emotionen 


\section{Introduction}

A transnational perspective on movement allows us to explore the continuing social, economic and political ties that migrants maintain and create between 'there' (where they have left, the sending society) with 'here' (point of arrival, the host society) (cf. Grillo/Riccio/Salih 2000; Vertovec 1999). Such a focus on migration has been significant for understanding the lived experiences of individuals or groups such as families (cf. Basch/Glick-Schiller/Szanton-Blanc 1994; Bryceson/Vuorela 2002). Prior understandings of migration have failed to address 'the continuing interaction between migrants and their homelands and the importance of this interaction for successive migrant generations' (Skrbis 2007, p. 262). Rather than assume that familial ties dissolve as a result of migration a transnational perspective reveals that families are dynamic and responsive to being stretched across place (see various contributions to Grillo/Gardner 2002). In South Asia decisions about migration are said to occur in the context of the household (cf. Gardner 1995) and much of the emphasis has been on ethnicity and kinship for the creation and maintenance of transnational ties (cf. Ballard 1994). Furthermore, there is an increasing recognition of gender and the intersection with the life course for the experiences of transnationalism (cf. Gardner 2002; Mand 2005). A gendered analysis has been of enhanced significance given the emphasis in early studies of South Asian migration (reflecting an empirical reality), on South Asian male (labour) migrants, resulting in a marginalisation of women's experiences. Instead, there is now a more nuanced understanding for the transformation migration brings to gender norms and practices within families (cf. Mand 2002; Mand 2005; Gardner 2002; Gamburd 2000; for a broader overview see Mahler/Pessar 2001).

The focus on marriage migration (including rituals) (cf. Mand 2002; Charsley 2012), remittances (cf. Gardner 1995), and roots tourism amongst the second generation (cf. Kaur/Hutnyk 1999; De Hanas 2013) has been key for understanding South Asian transnationalism. Within this literature there has been a focus on different generations, namely in terms of cohorts (i.e. first or second generation) and ensuing issues such as intergenerational negotiations specifically around marriages, integration and settlement. Less attention has been paid to the ways in which children are involved in intergenerational negotiations, or their experiences of transnationalism. As Levitt/Waters (2002) argue the 'concept of transnational migration, and its theoretical elaboration, must grapple with the question whether it extends beyond the immigrant generation' (p. 3). Although, there is growing recognition in the wider literature on the role children play in familial migration strategies (cf. Laoire/Carpena-Méndez/White 2010; Orellana et al. 2001), South Asian children's experiences and practices have been non-existent (exceptions are Gardner/Mand 2012; Zeitlyn 2012) ${ }^{1}$.

This paper draws from the experiences of 11 year old British born children whose parents are Bangladeshi and maintain transnational ties between east London, namely the borough of Tower Hamlets and Sylhet, a north eastern district of Bangladesh. The research sought to address the omission of children in South Asian transnationalism, bringing to the fore their experiences and representations, and to ask how these can contribute to theorisations around migration, diaspora and identities. The paper illustrates that despite their invisibility children are active members of transnational families and, argues for a focus on emotional labour to address them as actively engaging with 'transnational 
ways of being' and 'transnational ways of belonging' (Glick-Schiller 2004). The paper critiques an overt emphasis on socialisation when addressing childhood mobility and suggests children are social actors whose emotional labour is an integral part of a transnational familial habitus. However, the degree and impact of children's agency in effecting change in the practices of familial transnationalism is difficult to claim, owing to their positions within Bangladeshi intra- and intergenerational norms and, as we shall discuss, their emplacement in schools on account of their British citizenship (cf. Tidall/Punch 2012). Nonetheless, the paper argues for a focus on the emotional labour performed by children to understand the nature of their agency as they actively invest in transnational families. The lens of emotions highlights power relations amongst transnational kin networks within which children experience transnational mobility and the significance of wider socio-economic inequalities between London and Sylhet (cf. Gardner/Mand 2012; De Hanas 2013).

\section{Locating childhood and emotions}

Emotions can be approached through several lenses; they can be seen as embodied or discursive. The emphasis can be on materiality and on the role culture plays (cf. Lutz/White 1986). Emotions are a way through which we can explore agency and rather than assume they are by product, emotions 'involve an active engagement with the world and intimate connection with self and culture' (Williams/Bendelow 1998, p. xvi). Constructs of children as irrational, being driven by emotions, as unruly and necessitating control lends itself to locating them as being closer to nature, in stark contrast to 'adult' rationality (Williams/Bendelow 1998). Notions about childhood based on nature were popular during the era of Romanticism, which followed and were in contrast to Puritanical depictions of children as morally corrupt (cf. Montgomery 2003). Emotions are at the base of dualist constructs about childhood; for example Dionysian children are considered as unruly, devil like, irrational and emotional, whilst Apollonian children are, angelic, innocent, contained and emotionally stable (cf. Jenks 1996).

Locating social constructions about childhood is key feature of the "new social studies of childhood' paradigm, wherein childhood was re-conceptualized as a social and discursive construct, the experience of which is embodied according to space and in which children are active agents (cf. James/Prout 1997). The emphasis on children as agents had been an important intervention, however there have been calls to address how, where and to what effect can we understand childhood agency (cf. Tisdall/Punch 2012). Drawing from Mayall's (2002) work, we can note that there is a distinction between an actor who simply can do something and an agent, whereby the latter's actions brings about a difference in negotiation with others. Tisdall/Punch's (2012) review outlines varying suggestions for understanding childhood agency in a more nuanced manner. These include addressing agency as part of a continuum, as dynamic, as constrained (much like adults) and how perceptions about agency are contextual. As we shall see, children are active through emotional labour although the overarching socialization framework within which their experience of familial transnationalism is understood overshadows their agency. At the same time, emotions are an important aspect of familial life, and are a 'constitutive part of the transnational family experience itself' not least owing to the 'existence of emotional 
ties that inevitably link families' across geographic place. Transnationalism 'is a process that dissociates [and reunites] individuals from their family and friendship networks, as well as other socially significant referents that have strong emotional connotations' (Skrbis 2008, p. 236, emphasis mine). Nonetheless, there has been no dedicated exploration of understanding childhood and emotions in the context of migration (cf. Murray/Mand 2013). By locating children as active agents and moving away from addressing emotions as part of an inherent unconscious nature posits children as sentient actors. The sentient actor is responsive, emotional, alert and dynamic (cf. Hochschild 1975).

\section{A note on methodology}

The research took place over the course of three years in the London borough of Tower Hamlets where large numbers of Bangladeshis reside, amongst whom there is a higher than national average number of children (cf. Population Key Facts 2013). Access to children was through a primary school, and initial contact occurred when they were approximately eight years old. Of the forty eight children in the cohort $90 \%$ were of Bangladeshi background. With the exception of two, all the children of Bangladeshi heritage were born in London and most recorded having been to Bangladesh twice by the age of ten. One of the aims of the research was to develop creative and innovative ways of conducting migration research, and the broader ethos of the research design was to be child centred (cf. Mand 2011).

A host of research methods were deployed over the course of time, starting with observations in the classroom and mapping and ranking activities with the children in the playground, to more formal semi-structured interviews, diary writing, and arts based participatory methods by the end of the project. Participatory research practices have their basis in the field of development studies and aim to be more inclusive, hence the approach relies less on scribal and more on representation (using accessible materials in rural areas like sticks, beans) and in this research children undertook artwork (cf. McTaggart 1997). With regards to children this approach has been increasingly popular given the emphasis on child rights enabling children's 'voices' (i.e. United Nation Conventions; Tisdall/Punch 2012). Ideals inherent within participatory approaches and giving 'voice' were problematic during this research (cf. Mand 2011). As part of this research, alongside the lead researcher, the children also worked with two practicing artists producing art work of both a two and three dimensions which was then exhibited at the local Museum (cf. Mand 2011). Owing to the different methods used over the course of the research, we generated visual, scribal as well as oral data. For the purposes of this paper, children's interviews were analysed thematically and close attention was paid to the descriptions of, and sentiments about being in Bangladesh.

\section{Legacies of familial transnationalism}

There is a historical precedent amongst Bangladeshis of maintaining familial ties between London and Sylhet. Prior to the 1980s, pioneer male migrants took up employment in the 
UK leaving behind wives and children, all the while maintaining social relations through visits and sending remittances (cf. Gardner 1995). At the same time, wives left behind sent pickles and homemade food stuffs that symbolically connected male migrants to the nourishment of 'home'. Amongst the first generation, geographic places were thought of as imbuing particular capitals. Hence desh loosely translated as 'home' referring to Bangladesh where the male migrant would ultimately return, held spiritual capital whilst bidesh (England) was where economic capital could be gained (Gardner 1993). Amongst this generation it was male migrants who moved between England and Bangladesh, the former place being thought of as not suitable for women and children on account of perceived moral dubiousness. By the late 1980s, the process of family reunification in the UK, amongst the Bangladeshis was underway leading to the establishment of a second generation (cf. Gardner 1993, 1995). Broadly speaking, generational cohorts can describe migrants and their descendants (cf. Rumbaut 2004). For example one can identify the 'first' generation as Bangladeshi men who arrived as economic migrants when Britain was experiencing an economic boom and their offspring as second generation. However, the notion of generational cohorts does not reflect the reality of Bangladeshi transnationalism. For example, many of the children, from this research, recorded one or both parents to be born (and raised, indeed the second generation) in the UK, whilst a few stated one parent as a first generation migrant to the UK.

All bar a few, of the children had been to Bangladesh as part of familial visits, which are carefully planned for events requiring considerable material and social resources (cf. Gardner/Mand 2012; Zeitlyn 2012). Visits made to family members in Bangladesh involve attending a variety of events such as wedding and religious festivals, and visiting kin in different parts of the district. In some cases, children described cousins in London being in Bangladesh at the same time, underlying the different functions, literal and symbolic, that visits entail (cf. Olwig-Fog 2002 for a Caribbean account). From a parent's point of view, visits are necessary for they provide opportunities for acculturation and developing familial bonds, as one mother Rashida, explained in relation to her 10 year old son:

'I want him to know his granddad, his aunties and uncles ... they are all there ... [if in] ten years' time ... he wants to do something for himself and he thought maybe [an] investment in Bangladesh ... he needs to be able to talk because he doesn't really know his way around in Bangladesh'.

\subsection{Intergenerational differences and feelings about a place}

We have heard how amongst an older generation of Bangladeshi migrants, the desh has been constructed as a site of spiritual substance. In contrast, children's accounts illustrate both Bangladesh and London to be part of 'home' and a key factor is the social relationships that glue home (and by extension belonging) in both places (cf. Mand 2010). A significant aspect of children's accounts about being in Bangladesh was the leisure activities that 'being there' afforded them. These include being able to play out in fields, shopping as well as trips to tourist sites and fun fairs (cf. Mand 2010; Gardner/Mand 2012). While there are differences in how children relate to place, the family is an important mode through which they envisage their relationship to place. Some of this was apparent in my observations of and interviews with Mad $\mathrm{Max}^{2}$. 
Mad Max's father migrated to London following his marriage to a British born Bangladeshi woman. His memories of 'being there' are infused with memories of the past and activities undertaken whilst on visits to the 'homeland'. One such visit was filmed on Digital Video Device (DVD) and shown to me when I went to visit Mad Max at his London home. The DVD depicted a feast that was held in honour of their return to Sylhet and several members of the extended family were said to be present. The father pointed to an adjoining piece of walled land next to the family homestead, which he described in detail and his hopes to construct a new house upon it. As I watched the video with the adults (parents), Mad Max went to his room periodically returning to see what we were doing. When I asked what he thought of the video he mentioned the bathing pond and street dogs, and his sadness at the death of one of the dogs.

Different experiences of place are apparent between Mad Max and his father, and yet Bangladesh is framed in familial terms, albeit possibly invented as this account by Mad Max about a picture of a waterfall (in Bangladesh) suggests:

Mad Max: My dad's been in a waterfall, ... but I never went there.

I: No? How do you know your dad's been?

Mad Max: Ah, there's a picture of it.

I: What, is it a waterfall like this?

Mad Max: Yeah. It's a waterfall like that. There's a little rock there. He's standing on the rock.

'Being there' is necessary for Mad Max's parents as it presents an opportunity to reconnect and to make present day investments, while in the case of Rashida it is for future social and material investments. Paying attention to children's accounts, however, highlights 'being there' as raising emotional states and these need to be read in light of parental expectations of connectivity. In the espousals of parents, children are expected to follow familial practices and it is within such constrains that their agency, as expressed through feelings needs to be addressed. As we shall see through Tamana's account (below), strong feelings exist about the different kin networks in the context of local and trans-local hierarchies within which children are moving. Additionally, 'being there' also raises emotions about being in and out of place based on the environment. Following Tamana's explanation the paper addresses the labour involved in familial transnationalism often spoken about in terms of 'adult' practices, which nonetheless is performed by children through emotional investments. Another example of this is the expectation that being in Bangladesh will mean that children will learn to communicate appropriately and the underlying assumption that they will maintain future connectivity between 'here' and 'there'. The labour performed by children to acquire the right cultural and social capital to be part of a Bangladesh transnational habitus (cf. Zeitlyn 2012) is immense. This is overlooked as visits are naturalized to be part of their socialization as children. Let us turn to what we know about children's visits so far.

\section{2 'Being there' and ambivalence}

Zeitlyn's (2012) focus on 'the visit' by children from north London to family members in Bangladeshi, is described as a period when children are socialized into a transnational habitus, albeit one that is gendered. Zeitlyn (2012) observed the encouragement of girls to be with other female kin, to learn traditional cooking practices and the ideals of Bangla- 
deshi womanhood. During these visits Zeitlyn (2012) suggests children learn 'what being Sylheti means; the extent to which they accept or resist socialization...varies.... Their disorientation and unease in Bangladesh creates ambivalent reaction to aspects of their visits' (p. 954). Ambivalence is a key motif in Bangladeshi ways of being, and telling troubles (cf. Wilce 1998) and as Gardner (1993, 2002) suggests is a part of the cultural contradictions of Bangladeshi transnationalism. For children, Zeitlyn accounts that ambivalence is a result of the limitations of their London based cultural capital in Sylhet, leading to bafflement and discomfort in 'being there'. Nevertheless, Zeitlyn underlines that through repetitious instructions on how to behave, the gendered emplacement of children within particular spaces leads them to 'learn to value and exchange correct forms of capital in the British Bangladeshi social field' (Zeitlyn 2012, p. 963). Whilst Zeitlyn (2012) draws attention to emotional experiences, notably children's discomfort leading to ambivalence, the overarching framework of seeing the visit largely as socialization fails to unravel emotions that make up children's ambivalence, and which reflect the nature of transnational familial ties. Indeed, one of the key aspects of 'being there' is the expectations on children to hold positive regard for family members located in Bangladesh. In the proceeding section I explore children's placement within trans-local networks governed by kinship norms, which form the context of them 'being there'. I suggest that a closer consideration of emotions brings to the fore the significance of structural (social and economic) constraints, through which we can explore the nature of children's agency in transnational families.

Like adults children are part of transnational families within which actors 'work out the nature of their relationships to other family members'. These relationships are inherently dynamic as there is a 'continual revision of one's role and family identity through the individual's life cycle' (Bryceson/Vuorela 2002, p. 15). Transnational familial ties 'aim at welfare and mutual support and provide a source of identity', but are nonetheless operating within power relations based on gender and generation (cf. Bryceson/Vuorela 2002, p. 7; Gamburd 2000; Mand 2005). Viewing families as being made up of positioned members according to gender and generational norms, which also alter owing to transnationality, brings to the fore the power dynamics in the 'inner workings' of families (cf. Bryceson/Vuorela 2002).

As part of transnational familial workings, visits children make are to maternal and paternal kin who more often than not live in different localities within Bangladesh. The eminence and numbers of maternal or paternal kin is dependent on the specificity of familial migration histories. In some cases, it was clear to see that children spent time with a particular parent's kin, in Bangladesh, as there were no counterparts from the other parent. On the whole, however, children spoke of visiting (at times in a confused manner) two sets of kin (maternal and paternal) and the experiences of being with these different groups of kin were not uniform. For example, Tamana, spoke about three visits she had made to the village in Sylhet, where she has an Uncle (father's younger brother) and his three sisters. During these visits less time was spent with her mother's sister (who lived at a distance from her father's kin), while other members of her mother's family (her grandmother, grandfather, three aunts and one uncle) live close to Tamana's home in Tower Hamlets. The majority of her time, in Sylhet, was spent at her uncle's house consisting of two rooms where her uncle, his wife and children lived alongside two aunts (father's sisters). Tamana described the living situation and social relations in the following manner: 
Tamana: Yeah a corridor. If you go through the corridor you'll see a big, big room and then there's a bed there, a bed there and then my dad's sister sleeps there and my other dad's sister sleeps there. They are my dad's sisters and poor ... very poor. The first one ... she was really poor and the next one, she's all brown and she's really, really poor too. The other one is a little bit poor and we went to their house ... cos we never went to my other one [third sister's house] ... he's [third sister's husband] is really black!

In contrast, Tamana said 'if you go to my mum's sister's house ... if you go to that house you might get lost ... there are so many rooms inside the house ...' The (maternal) aunt's house has fewer residents, with only a quiet and accomplished teenager residing there, in contrast to her (paternal) uncle's home where there are many cousins who are 'rude and one day they gave [them] bad food and then we had tummy aches'.

Tamana's experience highlights children's transnational visits to involve movement between different socio-economic statuses within and between trans-localities. For example, between London and Sylhet children move between different socio-economic realities owing to wider global economic inequality. Therefore, in Sylhet they are part of an elite group referred to as Londonis on account of their access to what London represents (materially and symbolically) whilst in London they are members of the city's poorest communities (cf. Gardner/Mand 2012). At the same time, this is replicated within a locality (Bangladesh) moving between kin who in turn hold different socio-economic positions. For example, Tamana's description of one of the aunts and her husbands as 'really black' depicts them as impoverished while reference to skin colour (perhaps) implies them to be labouring under the sun. A socio-economic perspective on the visit enables an analysis of Tamana's feelings about being in, and part of, different houses and social relations which translate to being upset, hurt and bewildered. Furthermore, being on the move between an impoverished uncle's home and an affluent aunt is resented as the Bangladeshi norms of patrilocal residence mean she spends the majority of her time begrudgingly at her uncles (father's brother). The discomfort and unease that gives rise to ambivalence about 'being there' is based on incongruities of place and people relative to what the ideals of transnational families are. A focus on visits as a time for socialization, whilst a truism in that children are instructed into language and ways of engaging with the world, nevertheless should not preclude analyzing this in the context of adult- child power relations (cf. Alanen 1988) and one could add relations amongst trans locally and nationally located kin.

Therefore, aunts and uncles (adults) who one 'must' love and respect are experienced with suspicion (of making Londoni families ill) and disdain. It is the senses (feeling ill) which are the 'generators of affect, whether through interactions with the environment or other people' (McKay 2005, p. 78), that inform children's emotions. This can be as a result of the physical discomfort associated with travel (ear ache; upset stomachs), being in a particular geographic environment (heat, dust, dirt, space) or on the technical aspects (loss of passports, overweight suitcases (cf. Murray/Mand 2013). Moreover, in children's accounts of mobility the senses are elevated and these are relayed through emotions about space and place (cf. Murray/Mand 2013). Furthermore, the trope of bodies is significant in Tamana's account suggesting a closer examination of the connections between senses and emotions in children's account of transnational families (cf. Mand forthcoming). When asked the question as to where she felt rich or poor, Tamana's response exhibited anger and frustration at the nature of transnational kinship practices: 
I: So why are you poor in Bangladesh?

Tamana: Because Bangladesh IS poor and ... every time we have to be poor ... sometimes in London we are poor because Bangladesh people ... they just ... if their uncle is very stupid ... he says to me ... NOT me ... my dad ... 'Give me money, give me money, I want to make more houses!' We don't like that. When we give all that money they just eat it all'.

$[\ldots]$

I: Who do you feel close to in Bangladesh, who do you feel is very important to you there? Your aunt?

Tamana: Yeah my aunt ... she is very kind to me and when I was sick she always feeded me because my mum went to Sylhet and everybody went there and me and my little sister, we were in her house ... I didn't want to eat and then my mum said 'Keep her safe'

I: She kept you safe?

Tamana: Mum trusted her ... that's her sister.

Getting ill is an experience of being in Bangladesh, for Bangladesh is so poor that even the rich get poor. However, Tamana links poverty to bodily depletion, through the demands of kin (in Bangladesh) for money and by extension nourishment. There is a cost of the geographic inequality within which children are mobile, comprehended through the senses which make local kin 'immune to 'bad food' in contrast to making them (from London) become poorly. In their study of a transnational family reunion, based on the account of Marcela (who is one of the authors), Ramirez/Skrbis/Emmison (2007) draw attention to positive emotional experiences in visiting kin living in the diaspora, due to the relative socio-economic equality in migration destinations. This is in contrast to the reunion in El Salvador, the 'home land' where the emotional dynamics of visits are uncomfortable owing to socio-economic structural factors that 'shape(d) the course of interaction' amongst family members (Ramirez/Skrbis/Emmison 2007, p. 427; Svasek/Skrbis 2007).

\section{Emotional work and labour: Children's investments in transnational families}

A distinction is often made between child labour and child work, the latter denoting activities that are considered domestic tasks and are non-hazardous (cf. James/Jenks/Prout 1998). Explorations about childhood labour tends to be predominantly on their labour in the public sphere as workers in the global South, where children are often perceived to be exploited. Child labour more explicitly, denotes that children have an exchange value (cf. Hochschild 1983); although at times there is a slippage between their work and labour (for example see Unicef 2014). Drawing from the literature on child labour is useful because, as critics point out, the notion that child labour in the global South is exploitative per se, and the need to abolish it, presents a legitimate arm for interventions by the global North. These interventions are based on a construction of childhood as a period of vulnerability and dependency (Morrow 1996; Nieuwenhuys 2010). Furthermore, Niueuwenhuys (1996) highlights that the interventionist agenda negates children are active agents and draws them into dependency on the State and the family.

Dependency on the State and the family is a feature of childhood in England, where since the late $19^{\text {th }}$ century children's presence has shifted from the factory floor to the classroom. Historically, the growth in technological advancements in the textile industry, where children were employed, fused with changing ideologies about childhood. In par- 
ticular children, and especially working class children, were positioned as needing civilizing best achieved through schooling (cf. Morrow 1996). Today, in the UK, attending school is compulsory and a plethora of legislation exists nationally to regulate children's employment, with local bylaws governing the hours, conditions and places of work suitable for children. The overarching context for children is school, which as Bendelow/Mayall (2002) suggest are spaces that regulate, survey and aim to civilize children into adult agendas within which children learn to become productive citizens of a nation. The movement away from factory to classroom excludes children from gaining access to economic resources and related agency, and over time adults have 'become their [children's] protectors and nurturers and they have become our primary love objects, our human capital and our future' (Jenks 1996, p. 4). Hence, whilst their labour in the public sphere of factories is defunct in the global North, children's labour in spaces such as schools and families is unrecognized. This oversight is bolstered by the dominance of the socialization thesis which relates to childhood as a vulnerable phase and, children as passive receivers, hence the flow is from adult to child. As a result little attention is paid to children as 'love objects', performing for the emotional satisfaction of adults or at the very least recognition of the interdependency between adults and children (cf. Alanen 1988).

These constructions around childhood mean that children are 'emplaced' socially and physically according to notions of suitability decided by adults (cf. Olwig-Fog/Gullov 2003). In the global North children are legally emplaced in schools or families and these in turn determine what childhood is and what children can do. The notion of emplacement aids our understanding of the relationship between children's labour and citizenship, as it structures children's ways of being transnational. For example, children's emplacement as British citizens in British educational institutions means an emphasis on learning in the context of school. Hence travel to and from places (Bangladesh) occurs within particular windows of time. Not adhering to local authority rules concerning term-time absenteeism led, in the case of one child following an extended visit to Bangladesh, to losing his place at the State run school.

In the following section I explore how we can look at children's labour on account of them being emplaced in institutional contexts such as the workplace, schools and families. Although there is a wider literature that explores domestic work as labour (cf. Oakley 1974), the ideological underpinnings of what childhood is, makes children's domestic labour invisible. Morrow (1996) explains that children's work in the domestic sphere in the United Kingdom, consisting of cooking cleaning and care work, is negated as a result of the dominant perception that they are dependents. Instead, through her analysis, Morrow (1996) illustrates there to be interdependency between adults and children in familial life. Furthermore, she notes that although feminists highlight the gendered implications of domestic work, whereby girls perform tasks indoors and boys outdoors, the emphasis tends to be about role learning, rather than the actual (physical) labour and contribution children make (cf. Morrow 1996).

Let us now turn to an example of children's labour within transnational families:

Nasreen: 'he's my, he's a new born baby and, and I want to meet him and I always want, I always love Bangladesh and my mum said we might go in the summer holidays .... when I go cause like, we need to see the baby and we have say, to see everyone there and, and, and I need to see my grandma cause she's really ill...? [she will take him her] favourite little teddy bear and give it to my, the ba- 
by, the new born baby...he might like it... [when] he grows up, he can come when he gets married, when, he'll come and visit me, in London'.

The labour that children like Nasreen, Tamana and Mad Max perform are based on feelings which, as Hochschild (1975) suggests, occur within rules deemed normative and appropriate and which are frames of expression targeted for particular (political) ends. Nasreen's account of being part of, and apart from, family members induces feelings of longing and expressions of care appropriate for her gendered identity and age (gift of a teddy bear). Nasreen's feelings can be approached through the lens of 'language socialisation' which is common practice in Bangladeshi villages and 'stresses the active role of novices [children] in the socialization process' (Wilce 1998, p. 106). Therefore, her repeated symbolic claims of the baby being hers and gendered expressions of attachment enables an understanding of her agency. Nasreen's declaration that she '(I) want' to give the gift of a teddy bear reveals her to be a sentient actor and her ways of telling indicate how 'Bangla language socialization trains children to act selfhood in hierarchically bonded relationships' (Wilce 1998, p. 115). Furthermore, she demonstrates 'feeling rules' such as it is appropriate for females to seek to care for and, in being older, to want to look after younger and frail kin.

Children, much like the adults, through the emotion of 'longing for and missing people and places' are involved in 'kinship work' (Baldassar 2008, p. 250) The notion of 'kinship work' outlined by Alicea (1997), in her study of Puerto Rican transnationalism draws from di Leonardo's (1992) exploration of the role that women's labour, unpaid, plays in the sustenance of transnational ties. This labour includes amongst other things: 'ritual celebration of cross household kin ties, including visits, letters, telephone calls, presents, and cards to kin; the organisation of holiday gatherings; the creation and maintenance of quasi kin relations; decisions to neglect or intensify particular ties; the mental work of reflection about all these activities; and the creation and communication of altering images of family and kin vis-à-vis the images of others, both folk and mass media' (di Leonardo 1992, p. 248).

Whilst not specified, di Leornado's (1992) 'kinship work' is akin to Hochschild's (1983) notion of 'emotional work' which is unpaid and occurs within the private sphere and which holds use value notably in families. However in contrast to 'emotional work', 'emotional labour' for Hochschild (1983) is paid, occurs in the public sphere involves face to face interactions and necessitates management. Emotional labour is likely to be utilised for commercial ends and hence involves exchange value necessitating the management of feelings (cf. Hochschild 1975, 1983). The rigid distinction made between the public and private sphere makes it difficult to locate gendered and generational shifts and the blurring of boundaries in a transnational context. For example, Mand (2002) found that during the time of Sikh marriages in Tanzania older women were involved in the more domestic/local practices whilst men were involved in the public events such as organising immigration documents and transportation that mirrored patriarchal structures in the Tanzanian context. Nevertheless what remained central was the significance of both men's work and women's work for the maintenance of status as part of families and communities.

Additionally, inflexibility between the public/ private sphere and notions of labour/ work unwittingly marginalises the agency of children and the roles that they perform in a transnational social field. In this respect it is useful to consider Bolt (2001) who addresses 
emotional labour performed by nurses. Bolt (2001) draws from Goffman's 'presentations of the self' thesis to illustrate the many faces nurses have and how they present their competency as social actors performing in 'situated activity' (Bolt 2001, p. 87-88). In doing so Bolt underlines a related concept from Goffman, of the competent actor which 'provides the necessary 'conceptual connecting tissues' between the private and public worlds of emotion management and emphasising actors' multiple identities' (Bolt 2001, p. 88). Children are competent actors, as Nasreen indicates, where they present 'faces' that deliver an acceptable gendered performance of feelings of longing and care for others elsewhere. At the same time, children like Tamana are involved in managing difficult feelings in account of social relations and the shifting positions that they occupy in different translocalities. Being mobile between places and experiencing contradictory feelings is further enhanced by the onus on them to acquire the right capitals for being part of a transnational habitus. The inability to translate capitals, as Zeitlyn's (2012) describes, creating feelings of ambivalence.

\section{Conclusion}

Ambivalence is a key emotion attributed to transnational lives, however a closer inspection of the ways in which children narrate bodily sensations of being in and out of places, and by extension social relationships, allows us to address the emotional labour children perform as competent social actors in transnational families. Emotions are an integral part of being mobile, and children express these with an emphasis on the body and associated senses. These embodied experiences are part of a British Bangladeshi habitus, as their bodies move through places and associated social relations creating embodied knowledge acquired through labour. Children like Nasreen are overtly involved in emotional labour and through her emotions of 'longing' she maintains connectivity from the past, present and into the future. The baby is imagined as older, by Nasreen and, like her, mobile, collapsing spatial and temporal distinctions. In contrast, keeping trans-local kin relations is not desirable for Tamana as transnational alliances can and do result in loss (of resources and by extension health). Nonetheless, feelings of suspicion and disdain are contextual, for Tamana illustrates differing emotions depending on which family members she is with.

In this paper, I have illustrated functional understandings of the 'visit' children make to Sylhet, as occasions for socialization fail to account for the emplacement of children in generational structures. Therefore, although the (adult) rationale for being in Bangladesh structures children's presence and experiences of 'being there', the lens of emotions allows us to comprehend children's labour as agency (cf. James/Prout 1997). It rests on children to be adaptable to achieve the right capital for a British Bangladeshi habitus and to manage being part of/moving between different socio-economic realities and social relations. Such management occurs at the level of emotions and is imbued with feeling, whether these are ambivalent or not, nevertheless requires a closer look at emotions and childhood.

A necessity for understanding children's labour is to explore their positions in transnational kin networks. To suggest that children passively occupy positions fails to locate their agency, as social actors involved in performing labour within particular spaces. Indeed, as 
indicated earlier, children are in a process of labouring in schools and families although predominant ideological underpinnings around childhood fail to recognise this. Being in Bangladesh is rationalised by adults, for purposes of socialisation, into appropriate social relations and language. It nevertheless involves labour/agency to become competent members of, as Zeitlyn (2012) names it, a British-Bangladeshi habitus. These visits, involve labour which occurs in a transnational social field that is at once public as it is private. For, while visits take place in the context of families, they nevertheless encompass public displays of British- Bangladeshi mobility. In this paper, we have seen that a focus on emotions allows us to explore children's practices and experiences of transnationalism and further our understanding of British Bangladeshi transnational families.

\section{Notes}

1 Work undertaken by Mand, Gardner and Zeitlyn on Bangladeshi children is interconnected and is based on an Arts and Humanities Research Council funded project under the Diaspora, Migration and Identities scheme (2006-2010, A/HE508863/1). Zeitlyn was a doctoral student. I would like to thank the anonymous reviewers of this paper for their constructive comments.

Children chose their own pseudonyms.

\section{References}

Alanen, L. (1988): Rethinking Childhood. Acta Sociologica, 31, 1, pp. 53-67.

Alicea, M. (1997): 'A Chambered Nautilus': The contradictory nature of Puerto Rican women's role in the social construction of a transnational community. Gender and Society, 11, 5, pp. 597-626.

Ballard, R. (Ed.) (1994): Desh Pardesh: The South Asian Presence in Britain. - London.

Basch, L./Glick-Schiller, N./Szanton-Blanc, C. (Eds.) (1994): Nations Unbound: Transnational projects, postcolonial predicaments, and deterritorialized nation-states. - New York.

Bendelow, G./Mayall, B. (2002): Children's Emotional Learning in Primary Schools. European Journal of Psychotherapy, Counselling and Health, 5, 3, pp. 291-304.

Baldassar, L. (2008): Missing Kin and Longing to be Together: Emotions and the Construction of Copresence in Transnational Relationships. In: Svašek, M. (Ed.): Transnational Families and Emotions, Special Issue, Journal of Intercultural Studies, 29, 3, pp. 247-266.

Bolt, S. (2001): Changing faces: nurses as emotional jugglers. Sociology of Health and Illness, 23, 1, pp. 85-100.

Bryceson, D./Vuorela, U. (Eds.) (2002): The Transnational Family. New European Frontiers. - Oxford.

Charsley, K. (Ed.) (2012): Transnationalism, Migration and Marriage. - Oxon.

De Hanas, D. N. (2013): Of Hajj and home: Roots visits to Mecca and Bangladesh in everyday belonging. Ethnicities, 13, 4, pp. 457-472.

di Leonardo, M. (1992): The female world of cards and holidays: women, families and the work of kinship. In Thorne, B./Yalom, M. (Eds.): Rethinking the Family: Some Feminist Questions. - Boston.

Gamburd, R. (2000): The Kitchen Spoon's Handle: Transnationalism and Sri Lankan Migrant Housemaids. - Ithaca/London.

Gardner, K. (1993): Desh and bidesh: Sylheti images of home and away. Man, 28, 1, pp 1-15.

Gardner, K. (1995): Global migrants, local lives: Travel and transformation in rural Bangladesh. - Oxford.

Gardner, K. (2002): Narrative, Age and Migration: Life history and the Life Course Amongst Bengali Elders. - London.

Gardner, K./Mand. K. (2012) 'My Away is Here': Place, Emplacement and Mobility amongst British Bengali Children. In: Gardner, K./Mand, K. (Eds.): Through Children's Eyes: Transnational Migration Reconsidered. Journal of Ethnic and Migration, 38, 6, pp. 969-986. 
Glick Schiller, N. (2004): Transnationality. In: Nugen, D./Vincent, J. (Eds.): A Companion to the Anthropology of Politics. - Malden, MA, pp. 448-467.

Grillo, R. B./Riccio, R./Salih, R. (2000): Here or There? Contrasting experiences of transnationalism: Moroccans and Senegalese in Italy. - Brighton.

Grillo, R. B./Gardner, K. (2002): Transnational households and rituals: an overview. Global Networks, 2, 3, pp. 179-190.

Hochschild, A. R. (1975): The Sociology of Feeling and Emotion: Selected Possibilities. Sociological Inquiry, 45 , pp. $280-307$.

Hochschild, A. R. (1983): The Managed Heart: Commercialization of Human Feeling. - Berkeley.

James, A./Jenks, C./Prout, A. (1998): Theorizing Childhood. - London.

James, A./Prout, A. (Eds.) (1997): Reconstructing Childhood. - Basingstoke.

Jenks, C. (1996): Childhood. - London.

Kaur, R./Hutnyk, J. (Eds.) (1999): Travel Worlds. Journeys in Contemporary Cultural Politics. - London/New York.

Laoire, C./Carpena-Méndez, F./Tyrrell, N./White, A. (Eds.) (2010): Childhood. A Journal of Global Child Research, 17, pp. 273-287.

Levitt, P./Waters, M. C. (2002): The Changing Face of Home: the transnational Lives of the Second Generation. - New York.

Lutz, C./White, M. (1986): The Anthropology of Emotions. Annual review of Anthropology, 15, pp. 405436.

McKay, D. (2005): Migration and the Sensuous Geographies of Re-emplacement in the Philippines. Journal of Intercultural Studies, 26, 1-2, pp. 75-91.

McTaggart, R. (Ed.) (1997): Participatory action research: International Contexts and Consequences. Albany, NY.

Mahler, V./Pessar, S. (2001): Gendered Geographies of Power: Analyzing Gender Across Transnational Spaces. Identities: Global studies in Culture and Power, 7, 4, pp. 441-460.

Mand, K. (2002): Place, gender, power in transnational Sikh marriages. Global Networks, 2, 3, pp. 233248.

Mand, K. (2005): Marriage and migration at the end stages. Indian Journal of Gender Studies, 12, 2/3, pp. 407-425.

Mand, K. (2010): 'I've got two houses, one in Bangladesh, one in London. Everybody has!' Home, locality and belonging(s) in the east End. In: Laoire, C./Carpena-Méndez, F./Tyrrell, N./White, A. (Eds.): Childhood. A Journal of Global Child Research, 17, pp. 273-287.

Mand, $K$. (2011): Innovative methods and creative research with children in transnational families. The International Journal of Social Research Methods, 15, 2, pp. 149-160.

Mand, K. (forthcoming, 2016): The body in (e)motion: Diasporic childhoods and global/local. Ethnologia Fennica.

Mayall, B. (2002): Towards a Sociology of Childhood: Thinking from Children's Lives. - Buckingham.

Morrow, V. (1996): Rethinking Childhood Dependency: Children's Contribution to the Domestic Economy. The Sociological Review, 44, 1, pp. 58-77.

Montgomery, H. (2003): Major themes in Western constructions of childhood. In: Woodhead, M./Montgomery, H. (Eds.): Understanding Childhood. An interdisciplinary Approach. - Milton Keynes, pp. 61-67.

Murray, L./Mand, K. (2013): Travelling near and far: researching children's mobile emotions. Emotions, Space and Society, 9, pp. 72-79.

Nieuwenhuys, O. (1996): The paradox of child labour and anthropology. Annual Review of Anthropology, 25 , pp. 237-251.

Nieuwenhuys, O. (2010): Keep asking: Why childhood? Why children? Why global? Childhood, 17, 3 , pp. 231-296.

Oakley, J. (1974): The sociology of Housework. - London.

Olwig-Fog, K. (2002): A wedding in the Family: home making in a global kin network. Global Networks, 2, 3, pp. 205-218.

Olwig-Fog, K./Gullov, E. (Eds.) (2004): Children's Places. - London.

Orellana, M. F./Thorne, B./Chee, A./Lam, W. S. E. (2001): Transnational Childhoods: The participation of children in processes of family migration. Social Problems, 48, 4, pp. 573-592. 
Population Key facts (2013): A profile of the population of Tower Hamlets. Available at: http://www. towerhamlets.gov.uk/lgsl/901-950/916_borough_profile/research and briefings/demography.aspx, date accessed: $16 / 12 / 14$.

Ramirez, M./Skrbis, Z./Emmison, M. (2007): Transnational Family Reunions as Lived Experience: Narrating an El Salvadoran Ethnography. Identities: Global Studies in Culture and Power, 14, 3, pp. 411-431.

Rumbaut, R. G. (2004): Ages, Life Stages, and Generational Cohorts: Decomposing the Immigrant First and Second Generations in the United States. International Migration Review, 38, 3, pp. 11601205.

Skrbis, Z. (2008): Transnational Families: Theorising Migration, Emotions, and Belonging. Journal of Intercultural Studies, 29, 3, pp. 231-246.

Svasek, M./Skrbis, Z. (2007): Passions and Powers: Emotions and Globalisation. Identities: Global Studies in Culture and Power, 14, 3, pp. 367-383.

Tidall, K. E./Punch, S. (2012): Not so 'new'? Looking critically at childhood studies. Children's Geographies, 10,3 , pp. $249-264$.

Vertovec, S. (1999): Conceiving and Researching Transnationalism. Ethnic and Racial Studies, 22, 2, pp. 447-462.

Unicef (2014): Understanding Children's Work. Available at: http://www.ucw-project.org, date accessed: $16 / 12 / 14$

Wilce, J. (1998): Eloquence in Trouble. The Poetics and Politics of Complaint in Rural Bangladesh. Oxford.

Williams, S./Bendelow, G. (Eds.) (1998): Emotions in Social Life: Critical Themes and Contemporary Issues. - London.

Zeitlyn, B. (2012): Maintaining transnational social fields, the role of visits to Bangladesh for British Bangladeshi children. Journal of Ethnic and Migration Studies, 38, 6, pp. 953-968. 